\title{
The potential source for composite flours as food ingredient from local grown crops
}

\author{
1, ${ }^{*}$ Zainol, N., ${ }^{2}$ Subramanian, S., ${ }^{2}$ Adnan, A.S., ${ }^{2}$ Zulkifli, N.H., ${ }^{2}$ Zain, A.A.M., ${ }^{2}$ Kassim, \\ N.R.W. and ${ }^{2}$ Kamarudin, A.A. \\ ${ }^{1}$ Institute of Bioproduct Development (IBD), Universiti Teknologi Malaysia, 81310 UTM Johor Bahru, \\ Johor, Malaysia. \\ ${ }^{2}$ Faculty of Medicine and Health Science, Universiti Putra Malaysia, Serdang, Malaysia.
}

Article history:

Received:

Received in revised form:

Accepted: 8 August 2020

Available Online: 9 August 2020

\section{Keywords:}

Physicochemical properties, Local crops,

Mineral and heavy metal analytes

DOI:

https://doi.org/10.26656/fr.2017.4(S2).S11

\begin{abstract}
The market of composite flour is growing as consumer nowadays choosing a healthy diet as personal preference. The suitability of the composite flour for use as intermediate or finish food ingredients highly depends on its physicochemical properties and its nutritional value. In this study, four types of local fruit crops (particularly their seeds) namely rambutan, cempedak, durian and nangka were dried and ground into powder form. The physicochemical properties such as bulk density, $\mathrm{pH}$, water absorption capacity (WAC), oil absorption capacity (OAC), foam stability (FS), foam capacity (FC) as well as gelatinization properties of these composite flour were studied. Mineral content and heavy metal analytes were also determined. Results for bulk density from the least to the higher amount was $0.54 \pm 0.00 \mathrm{~g} / \mathrm{mL}, 0.57 \pm 0.00 \mathrm{~g} / \mathrm{mL}, 0.58 \pm 0.01 \mathrm{~g} / \mathrm{mL}, 0.66 \pm 0.00 \mathrm{~g} / \mathrm{mL}$, $0.70 \pm 0.00 \mathrm{~g} / \mathrm{mL}$ and $0.72 \pm 0.00 \mathrm{~g} / \mathrm{mL}$ for rambutan flour, cempedak flour, tapioca flour, nangka flour, wheat flour and durian flour, respectively. Both cempedak flour and nangka flour showed the lowest $\mathrm{pH}$ value $(5.72 \pm 0.01,5.73 \pm 0.00)$, followed by rambutan flour and durian flour $(6.67 \pm 0.00,6.90 \pm 0.00)$ which similar to that tapioca flour and wheat flour (6.65 $\pm 0.1,6.08 \pm 0.0)$, respectively. Rambutan flour, cempedak flour and wheat flours showed the highest value in $\%$ of foam stability meanwhile these composite flours showed the lowest value in $\%$ of foam capacity. Results for water absorption capacity (WAC) and oil absorption capacity (OAC) in a range of $6 \%$ to $42 \%$ and $8 \%$ to $12 \%$ respectively, however, durian flour obtained the highest value for WAC while the value for OAC was the lowest. All of the composite flour possesses gelling properties at $13 \%$ concentration except for cempedak flour which completely gels at $20 \%$ of concentration. Rambutan flour showed the highest mineral analyte particularly in Zinc (107.19 \pm 0.17$)$ and Copper

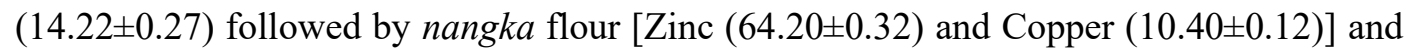
durian flour [Zinc (52.38 \pm 0.42$)$ and Copper $(7.97 \pm 0.05)$ ]. Level of heavy metal toxicity was under risk for all types of composite flour.
\end{abstract}

\section{Introduction}

Composite flours are a mixture of different vegetable flours rich in starch or protein, with or without wheat flour, for certain group of bakery products and its definition by Anon et al. (2018) is "composite flours are a mixture of flours from tubers rich in starch (e.g. cassava, yam, sweet potato) and/or cereals (e.g. maize, rice, millet, buckwheat), with or without wheat flour". Wheat flour is commonly used as it contains gluten which is responsible for the elasticity of the dough, improving the texture of the baked products. Gluten contains $75-86 \%$ protein and the remaining nutrients are carbohydrate and lipid, held strongly within the glutenprotein matrix (Anon et al., 2018).

There have been several studies conducted on fruits which have been combined with wheat flour to produce bakery products. A study done by Feili et al. (2014) reported that $5 \%$ substitution of the jackfruit rind flour gave the highest mark for overall acceptance compared to $10 \%$ and $15 \%$ substitution of jackfruit rind flour with wheat flour. Research by Papa Spada et al. (2018) reported that the jackfruit seed flour could be used in food preparation and has potential as cocoa powder substitute. Other studies conducted by Rohman (2017) 
stated that rambutan seed is a potential source of flour which is rich in carbohydrate. Nevertheless, other sources used to produce composite flour are from fruits as they contain a significant amount of vitamins, minerals and antioxidant properties as well as low in sodium, fat and calories (Nurul Izzah et al., 2012). The recent development in food industries used gluten-free composite flours to produce food products that are more suitable to people who have celiac disease or other health -conscious individuals. A wide range of healthy, glutenfree alternatives to regular or wheat flour exists for people with celiac disease, non-celiac gluten sensitivity or those avoiding gluten for other reasons. The worldwide number of sufferers of coeliac disease has been predicted to increase resulting in a growing market for gluten-free cereal-based products (Lebwohl et al., 2017). Yet, the suitability of the composite flour to be used in the food as a food ingredient are highly depending on the functional properties such as bulk density, $\mathrm{pH}$, moisture content, gelling concentration, gelatinization, water absorption capacity, oil absorption capacity and foam capacity and stability give effect to the texture of processed food. Functional properties are the intrinsic physicochemical properties that reflect the complex interaction between the composition, structure, confirmation and other food components which are associated (Chandra et al., 2015).

In general, Malaysian fruits such as rambutan, nangka and cempedak are abundant and it is becoming necessary to find a solution that could maximally utilize these crops through innovative product development. The need to fully utilize and reduce post-harvest losses of a local source is a major drawback to researchers in our country and also the lack of body of knowledge that adds to this issue. In addition, as there is an increasing demand using composite flours as a substitute for wheat flour for food products such as high-fibre bread, pasta, flakes and biscuits in commercial markets, the need to provide information on the scientific studies of composite flour is vital. For this purpose, the physicochemical properties of local grown fruits crops were studied. Adding up to the demand in composite flours with an adequate level of mineral and the toxicity level of heavy metal analytes, both analytes were also analyzed.

\section{Materials and methods}

Fresh and ripe fruits were bought from the market in Taman Universiti, Skudai, Johor. Wheat flour and tapioca flour were purchased from a grocery shop in Taman Universiti, Skudai and used as a benchmark.

\subsection{Preparation of composite flours}

The fresh fruits were washed before peeled to separate the seeds and its flesh. The seeds of each fruit were manually removed from pulp and washed to remove any adhering materials. The preparation of composite flours for each fruit was based on Menon et al., (2014). Each of these samples was then dried in a hot air oven at $60^{\circ} \mathrm{C}$ for 6 to $8 \mathrm{hrs}$. The dried samples were then milled and the grounded flour samples were sieved at $100 \mu \mathrm{m}$ mesh size to obtain fine texture flour. Lastly, samples were packaged in polyethylene bags and stored at room temperature for further use.

\subsection{Bulk density}

Bulk density was determined based on the method by Oladele and Aina (2007). A $10 \mathrm{~mL}$ graduated cylinder, previously tared, was gently filled with the sample. The bottom of the cylinder was gently tapped on a laboratory bench several times until there was no further diminution of the sample level after filling to the $10 \mathrm{~mL}$ mark. Bulk density was calculated as the weight of sample per unit volume of sample $(\mathrm{g} / \mathrm{mL})$.

\section{$2.3 \mathrm{pH}$}

The $\mathrm{pH}$ was measured by preparing a $10 \%(\mathrm{w} / \mathrm{v})$ suspension of samples in distilled water. The suspension was mixed thoroughly and the $\mathrm{pH}$ was measured (Model Mi 150).

\subsection{Moisture content}

The moisture content of samples was determined according to AOAC standard procedures (AOAC, 1975).

\subsection{Gelatinization}

The flour sample $(1 \mathrm{~g})$ was weighed and transferred to $50 \mathrm{~mL}$ centrifuged tube followed by $10 \mathrm{~mL}$ of distilled water. The suspension was gradually heated in water bath until they form a solid gel. At complete gel formation, the respective temperature was measured and considered as its gelatinization temperature which is based on the method by Chandra and Samsher (2013).

\subsection{Gelling concentration}

Gelling concentration was done employing the method by Adebowale et al. (2005). Sample suspensions containing 1, 7, 13 and $20 \%(\mathrm{w} / \mathrm{v})$ of flour concentration were prepared in $5 \mathrm{~mL}$ distilled water. The mixtures were heated in a boiling water bath for $1 \mathrm{hr}$ followed by rapid cooling under running cold tap water. The mixtures were allowed to further cool down for $2 \mathrm{hrs}$ at $4^{\circ} \mathrm{C}$. The least gelation concentration was determined as that concentration when the sample from the inverted test 
tube did not fall down or slip.

\subsection{Water absorption capacity (WAC)}

WAC of flours was carried out using the modified method of Akanbi et al. (2009). About $2 \mathrm{~g}$ of the sample was suspended in $20 \mathrm{~mL}$ of distilled water in a centrifuge tube. The sample was then stirred for $30 \mathrm{~s}$ at every 10 mins interval by using a glass rod. After 5 intervals, the mixture was then centrifuged at $4000 \mathrm{rpm}$ for 20 mins at $4^{\circ} \mathrm{C}$. Then, the supernatant was gently decanted and the content of the tube was drained at $45^{\circ}$ angle for 10 mins. The gel formed at the bottom of the centrifuge tube was then weighed. WAC was expressed as percentage increase of sample weight.

\subsection{Oil absorption capacity $(O A C)$}

OAC of the flour samples was done by employing the method by Adebowale et al. (2005) with some modifications. About $1 \mathrm{~g}$ of the flour sample was added to the tube and weight (labelled B). $10 \mathrm{~mL}$ of canola oil was added to the test tube and weight (labelled $\mathrm{C}$ ). The mixture of sample and oil were vortex for 1 minute and allowed to stand at room temperature for 10 mins then was centrifuged at $4000 \mathrm{rpm}$ for $30 \mathrm{mins}$ at $4^{\circ} \mathrm{C}$. The supernatant (unabsorbed oil) was decanted and the tubes were allowed to drain at a $45^{\circ}$ angle for about 10 mins and the residue weight (labelled D). The result was expressed as a percentage increase of the sample weight.

$$
\% \text { absorption }=\frac{D-B}{C-B} \cdot 100
$$

\subsection{Foam capacity and stability}

The foam capacity and foam stability were determined according to the method by Makri et al. (2005) with slight modification. About $1 \mathrm{~g}$ flour and 50 $\mathrm{mL}$ distilled water at room temperature were prepared in a calibrated centrifuge tube and whipped with a homogenizer for 5 mins to foam. The volume of foam at $30 \mathrm{~s}$ after whipping was expressed as foam capacity using the formula:

$$
\text { Foam capacity }(\%)=\frac{\text { volume of foam }(\mathrm{ml})}{\text { initial volume }(\mathrm{ml}) \text { before homogenization }} \times 100 \%
$$

After $1 \mathrm{hr}$ whipping, the volume of foam was recorded to determine the foam stability as percent of initial foam volume.

Foam stability $(\%)=\frac{\text { volume of foam }_{\text {after } 1 \text { hour }}-\text { volume of foam }_{\text {after } 30 \text { seconds }}}{\text { volume of foam }}$

\subsection{Mineral and heavy metal analytes determination (digestion procedure)}

For the digestion of the samples, a representative of $1 \mathrm{~g}$ of dry weight sample is digested with $1 \mathrm{~mL}$ of $60 \%$ analytical grade Nitric acid (Sigma Aldrich, Germany) and ultrapure water (Hitachi, Japan). The digestate was heated using a hot plate under boiling temperature until white vapour appeared. The sample was then diluted with ultrapure water until it reached a $100-\mathrm{mL}$ final volume. The sample is filtered using 0.25 nylon syringe filter and ready for Inductively Coupled Plasma-Mass Spectrometry (ICP-MS) injection. For the precise quantification of heavy metal and mineral analytes, calibration against synthetic standards was used before running the sample. $1000 \mu \mathrm{g} / \mathrm{kg}$ multi-element standard was used from Perkin Elmer standard solution and diluted to $10,20,30,50 \mu \mathrm{g} / \mathrm{kg}$ and $25 \mu \mathrm{g} / \mathrm{kg}$ as Quality Control (dissolved with $1 \%$ nitric acid (Sigma Aldrich, Germany). The data acquisition was done by ICP-MS Software (ELAN 6100, Perkin Elmer).

\section{Results and discussion}

\subsection{Physicochemical properties of composite flours}

Table 1 shows the data for the physicochemical properties of composite flours. In this study, the investigation of the physicochemical properties will provide information about the physical changes that may occur during the processing and development of food product. The parameter which discussed here includes bulk density, $\mathrm{pH}$, moisture content, water absorption capacity (WAC), oil absorption capacity (OAC), foam stability and foam capacity. Bulk density measures flour heaviness, defined as the ratio of flour weight to volume $(\mathrm{g} / \mathrm{mL})$. This enables one to predict its characteristics and compressibility of a food product. This is supported by Oulai et al. (2014) as they reported that this parameter determines the suitability for flours to facilitate in particulate foods packaging to maximize packing density of the powder for the efficiency of transportation. Based on Table 1, bulk density of composite flours varied from $0.54 \pm 0.00 \mathrm{~g} / \mathrm{mL}$ to $0.72 \pm 0.00 \mathrm{~g} / \mathrm{mL}$ with durian seed flour showing the highest value of bulk density $(0.72 \pm 0.00)$, while rambutan seed flour $(0.54 \pm 0.00 \mathrm{~g} /$ $\mathrm{mL}$ ) showing the lowest value of bulk density. High bulk density of flour suggests the suitability for use in food preparations especially as a thickener in food products since it helps to reduce paste thickness which is an important factor in convalescent and child feeding (Chandra et al., 2015).

The $\mathrm{pH}$ analysis of all composite flours was acidic varies from $5.72 \pm 0.10$ to $6.90 \pm 0.10$. Changes in $\mathrm{pH}$ values are directly related to the maturation stage of the fruits. Based on the result, durian has the highest $\mathrm{pH}$ value while cempedak has the lowest $\mathrm{pH}$ value as in Table 1. Considering the low $\mathrm{pH}$ of the composite flours evaluated in this study, it has a low risk of food deterioration by microorganisms, enzymes or nonenzymatic reactions (Damasceno et al., 2016). 
The moisture conditions of products are influenced by differences in variety, maturity and environmental conditions (Tortoe et al., 2014). Analysis of moisture content in the food industry is fundamental for guaranteeing the final product quality. Based on Table 1, the moisture content of composite flours varied from the lowest value to the highest value; $5.64 \pm 0.10$ to $11.91 \pm 0.20$ respectively. It can be observed that composite flours from the fruit's seed gave lower values compared to the wheat flour and tapioca flour. Therefore, it can be concluded that composite flour from the seed such as rambutan (5.64 \pm 0.10$)$, durian (8.18 \pm 1.60$)$, nangka $(8.66 \pm 0.00)$, and cempedak $(8.68 \pm 1.70)$ have the tendency of longer storage and better shelf life compared to the wheat flour $(11.80 \pm 0.10)$ and the tapioca flour $(11.91 \pm 0.20)$.

Water absorption indicates (WAC) the ability of the flour to absorb and hold water to achieve desired consistency and create a quality end product. Based on Table 1, the WAC of sample tapioca flour was $6.00 \pm 0.30 \%$ while that of sample durian was $41.55 \pm 2.90 \%$, indicating that durian flour has higher WAC. Therefore, it has a higher affinity for water which is informed by its lower moisture content. The ability of flour to absorb more water can improve the consistency and texture in food products. Increase in WAC is related to the fibre content due to increasing hydroxyl groups allowing more water interaction via hydrogen bonding (Chareonthaikij et al., 2016). These results suggest lower WAC may be useful for food formulations such as partial wheat flour replacer for dough handling in baking and pastry products (Chen, 2016)

Oil absorption capacity (OAC) is the ability of the flour to absorb and retain oil and reflects the emulsifying capacity of the flour thus it will contribute to the flavour that gives mouthfeel and increases soft texture to the mouth (Oulai et al., 2014). Based on results in Table 1, the OAC of rambutan flour, nangka flour and cempedak flour are $10.74 \pm 0.50 \%, \quad 10.39 \pm 1.70 \%, \quad 11.83 \pm 0.20 \%$ respectively which is slightly similar to tapioca flour $(10.68 \pm 0.20 \%)$. While durian flour and wheat flour having similar range value of OAC; $(8.76 \pm 0.90 \%)$ and $(8.84 \pm 0.20 \%)$ respectively. From the data, it is suggested that durian flour and the wheat flour will contribute less mouthfeel and decrease the soft texture in the mouth. On the other hand, the lower value of OAC will contribute to a lower degree of rancidity during the storage period. The ability of OAC is related to its amino acid composition, protein conformation and surface polarity or hydrophobicity (Chandra et al., 2015).

Foam capacity (FC) of protein refers to the amount of interfacial area that can be created by the protein while foam stability (FS) is defined as the ability of the protein to stabilize against gravitational and mechanical stresses (Fennama, 1996). Results for FC and FS are presented in Table 1. The FC of composite flours are varied from 4.0 to $32.0 \%$, with the highest FC was wheat flour $(32.0 \%)$ while the lowest FC were tapioca flour, durian flour and rambutan flour (4.0\%). On the other hand, the FS data are in the range from 0 to $100 \%$. The highest foam stability was observed for rambutan $(100 \%)$, followed by wheat flour (37.5\%), cempedak (25.0\%) and nangka (12.5\%). Interestingly, both tapioca flour and durian flour showed no foam stability. There was an inverse in the relationship between foam capacity and stability. Flour with high foaming ability could form large air bubbles surrounded by thinner less flexible protein film (Chandra et al., 2015). This air bubbles probably easier to collapse and consequently lowered the foam stability (Jitngarmkusol et al., 2008). In order to improve texture and sensory properties, other processing aids are added, including emulsifiers, stabilizers and including food hydrocolloid (Moore et al., 2006)

\subsection{Gelation properties of composite flours}

Table 2 shows the gelatinization properties of composite flour. Gelatinization temperature of rambutan flour, nangka flour, cempedak flour and wheat flour (> $90^{\circ} \mathrm{C}$ ) were slightly higher than that of durian flour and tapioca flour $\left(<85^{\circ} \mathrm{C}\right)$. Gelatinization temperature has been described as the point at which irreversible swelling of starch granules occur, resulting in the formation of a viscous paste. It is indicative of the minimum temperature required to cook starch/flour slurry and the energy costs involved (Chandar and Shamser, 2013). It was observed that (Table 2) only tapioca flour $\left(82^{\circ} \mathrm{C}\right)$, durian flour $\left(85^{\circ} \mathrm{C}\right)$ and nangka flour $\left(95^{\circ} \mathrm{C}\right)$ possess complete gelatinization. This is probably due to the

Table 1. Physicochemical properties of composite flours

\begin{tabular}{|c|c|c|c|c|c|c|c|c|c|}
\hline \multirow[b]{2}{*}{ Sample } & \multirow[b]{2}{*}{$\begin{array}{l}\text { Bulk Density } \\
\qquad(\mathrm{g} / \mathrm{mL})\end{array}$} & \multicolumn{2}{|c|}{ Foam } & \multirow[b]{2}{*}{$\mathrm{pH}$ value } & \multirow[b]{2}{*}{$\begin{array}{l}\% \text { Moisture } \\
\text { Content }\end{array}$} & \multicolumn{2}{|c|}{ Water Absorption Capacity } & \multicolumn{2}{|c|}{ Oil Absorption Capacity } \\
\hline & & $\begin{array}{c}\% \\
\text { Capacity }\end{array}$ & $\begin{array}{c}\% \\
\text { Stability }\end{array}$ & & & $\begin{array}{l}\text { \% weight } \\
\text { increase }\end{array}$ & $\begin{array}{l}\% \text { water } \\
\text { absorbed }\end{array}$ & $\begin{array}{l}\% \text { weight } \\
\text { increase }\end{array}$ & $\begin{array}{c}\% \text { oil } \\
\text { absorbed }\end{array}$ \\
\hline Rambutan & $0.54 \pm 0.00$ & 4 & 100 & $6.67 \pm 0.00$ & $5.64 \pm 0.10$ & $92.71 \pm 0.90$ & $10.16 \pm 0.10$ & $90.39 \pm 4.10$ & $10.74 \pm 0.50$ \\
\hline Durian & $0.72 \pm$ & 4 & 0 & & & $450.13 \pm 3.10$ & & $72.90 \pm 3.30$ & \\
\hline Nangka & $0.66 \pm 0.00$ & 16 & 12.5 & $5.73 \pm 0.00$ & $8.66=$ & $257.66 \pm 3.40$ & $27.12 \pm 0.60$ & $87.81 \pm 3.90$ & $10.39 \pm$ \\
\hline Cempedak & $0.57 \pm 0.00$ & 8 & 25 & $5.72 \pm 0.10$ & $8.69 \pm 1.70$ & $304.25 \pm 3.50$ & $31.73 \pm 4.00$ & $94.89 \pm 2.20$ & $11.83 \pm 0.20$ \\
\hline Wheat & $0.70 \pm 0.00$ & 32 & 37.5 & $6.08 \pm 0.00$ & $11.81 \pm 0.10$ & $151.56 \pm 3.90$ & $17.01 \pm 0.20$ & $69.37 \pm 2.90$ & $8.84 \pm 0.50$ \\
\hline Tapioca & $0.58 \pm 0.10$ & 4 & 0 & $6.65 \pm 0.10$ & $11.91 \pm 0.20$ & $53.95 \pm 2.40$ & $6.00 \pm 0.30$ & $88.20 \pm 3.40$ & $10.68 \pm 0.20$ \\
\hline
\end{tabular}


Table 2. Gelatinization properties of composite flours

\begin{tabular}{|c|c|c|c|c|c|}
\hline Gelling & $1 \%$ & $7 \%$ & $13 \%$ & $20 \%$ & Gelatinization \\
\hline Rambutan & No gel observed & $\begin{array}{c}\text { Slightly gelling } \\
\text { observed }\end{array}$ & Gelling observed & Gelling observed & $95^{\circ} \mathrm{C}$ (slightly gel $)$ \\
\hline Durian & $\begin{array}{c}\text { Slightly gelling } \\
\text { observed }\end{array}$ & $\begin{array}{l}\text { Slightly gelling } \\
\text { observed }\end{array}$ & Gelling observed & Gelling observed & $85^{\circ} \mathrm{C}$ (gel) \\
\hline Nangka & No gel observed & Gelling observed & Gelling observed & Gelling observed & $95^{\circ} \mathrm{C}$ (gel) \\
\hline Cempedak & No gel observed & $\begin{array}{l}\text { Slightly gelling } \\
\text { observed }\end{array}$ & $\begin{array}{l}\text { Slightly gelling } \\
\text { observed }\end{array}$ & Gelling observed & $95^{\circ} \mathrm{C}$ (slightly gel $)$ \\
\hline Wheat & No gel observed & Gelling observed & Gelling observed & Gelling observed & $95^{\circ} \mathrm{C}$ (slightly gel $)$ \\
\hline Tapioca & $\begin{array}{l}\text { Slightly gelling } \\
\text { observed }\end{array}$ & $\begin{array}{l}\text { Slightly gelling } \\
\text { observed }\end{array}$ & Gelling observed & Gelling observed & $82^{\circ} \mathrm{C}$ (gel) \\
\hline
\end{tabular}

higher amount of amylose and a greater degree of retrogradation which is caused by amylose-lipid complex in the granules being broken by heating (Chandar and Shamser, 2013).

Gelation is an aggregation of the denatured molecule and the ability of the protein to form gels and provide a structural matrix for holding water, flavours, sugars and food ingredients which is useful in food applications. Index of gelation (LGC) is observed from the characteristics of elasticity, viscosity and plasticity. The lower the gelation concentration, the better the gelating ability of protein ingredient (Akintayo et al., 1999) which results in the swelling ability of the flour is enhanced (Kaushal et al., 2012). All the samples completely formed gel at concentration $13 \%$ except for the cempedak flour which formed gel completely at the highest concentration of $20 \%$. This suggested that cempedak flour contain the lowest starch components which result in low thermal degradation of starch during the processing. This might be associated with the gelatinization ability of globulin ratio in flour (Wani et al., 2012). Meanwhile, wheat flour and nangka flour formed gel completely earlier than other samples which is at concentration $7 \%$. Therefore, flours with least gelation concentration are reported to be good thickening agents and hence, are not suitable for infant formulation since it requires more dilution (Appiah et al., 2011).

\subsection{Essential mineral and heavy metal analytes determination in composite flours}

Table 3 shows the essential mineral analytes of composite flour. Eleven mineral analytes were detected from the ICP-MS spectrometry. Among them, eight mineral analytes were at minimum detection (ppm) which were $\mathrm{Cr}, \mathrm{Ni}, \mathrm{Ag}, \mathrm{Be}, \mathrm{Co}, \mathrm{V}, \mathrm{Se}$ and $\mathrm{Sr}$ for all the composite flours. $\mathrm{Al}$ and $\mathrm{Zn}$ were the two mineral analytes that exist in a large amount in all composite flours. However, rambutan flours contained the highest amount of all analytes compared to the durian flours, the nangka flours and the cempedak flours. These analytes although exist in a minute quantity, they are important in maintaining many homeostatic mechanisms including efficiency of immune system as well as cell proliferation and genome stability (Bier et al., 2015). In addition, these minerals are required in a small quantity in our body. On the other hand, in this study, the heavy metal analytes of flours were also determined. Figure 1 shows the heavy metal analytes detected in the composite flour. Only three heavy metal analytes were detected in all composite flours namely Arsenic (As), Lead $(\mathrm{Pb})$ and Cadmium (Cd). As in Figure $1, \mathrm{~Pb}$ contributes the highest amount of heavy metal analytes in all the

Table 3. Mineral analytes detected in composite flour

\begin{tabular}{lcccc}
\hline \multirow{2}{*}{ Mineral analytes } & \multicolumn{4}{c}{ Concentration mean (ppm) } \\
\cline { 2 - 5 } & Durian & Rambutan & Nangka & Cempedak \\
\hline Aluminium, Al & $23.74 \pm 0.58$ & $47.13 \pm 0.48$ & $10.35 \pm 0.28$ & $41.37 \pm 0.05$ \\
Chromium, Cr & $2.12 \pm 0.08$ & $1.39 \pm 0.09$ & $1.79 \pm 0.01$ & $1.69 \pm 0.01$ \\
Nickel, Ni & $1.05 \pm 0.00$ & $2.81 \pm 0.12$ & $0.78 \pm 0.01$ & $0.48 \pm 0.00$ \\
Silver, Ag & $0.03 \pm 0.00$ & $0.07 \pm 0.00$ & $0.05 \pm 0.00$ & $0.11 \pm 0.00$ \\
Beryllium, Be & $0.01 \pm 0.00$ & $0.07 \pm 0.00$ & $0.01 \pm 0.00$ & $0.01 \pm 0.00$ \\
Cobalt, Co & $0.17 \pm 0.02$ & $0.07 \pm 0.01$ & $0.03 \pm 0.00$ & $0.03 \pm 0.00$ \\
Vanadium, V & $0.01 \pm 0.00$ & $0.07 \pm 0.01$ & $0.00 \pm 0.00$ & $0.00 \pm 0.00$ \\
Copper, Cu & $7.99 \pm 0.05$ & $14.22 \pm 0.28$ & $10.40 \pm 0.12$ & $5.24 \pm 0.00$ \\
Selenium, Se & $0.06 \pm 0.00$ & $0.15 \pm 0.02$ & $0.09 \pm 0.00$ & $0.10 \pm 0.00$ \\
Strontium, Sr & $2.47 \pm 0.06$ & $6.08 \pm 0.01$ & $5.20 \pm 0.14$ & $2.41 \pm 0.01$ \\
Zink, Zn & $52.38 \pm 0.42$ & $107.39 \pm 0.17$ & $64.23 \pm 0.32$ & $29.61 \pm 0.03$ \\
\hline
\end{tabular}


composite flours while the other two heavy metal (As and $\mathrm{Cd}$ ) were detected at the minimum level. The detection of $\mathrm{Pb}, \mathrm{Cd}$ and $\mathrm{As}$ is vital as these heavy metal analytes can lead to adverse effects, although they are only present in small quantity. From the data obtained (Figure 1), these three heavy metal analytes were detected to be below the maximum admissible limit (LMA) in the composite flours. The LMA of these heavy metal is $\mathrm{Pb}(1 \mathrm{mg} / \mathrm{kg})$, LMA of As $(0.02 \mathrm{mg} / \mathrm{kg})$ and LMA of $\mathrm{Cd}(0.05 \mathrm{mg} / \mathrm{kg})$ (Malaysian Food Regulation 1985). In general, all the composite flours were without risk of contamination

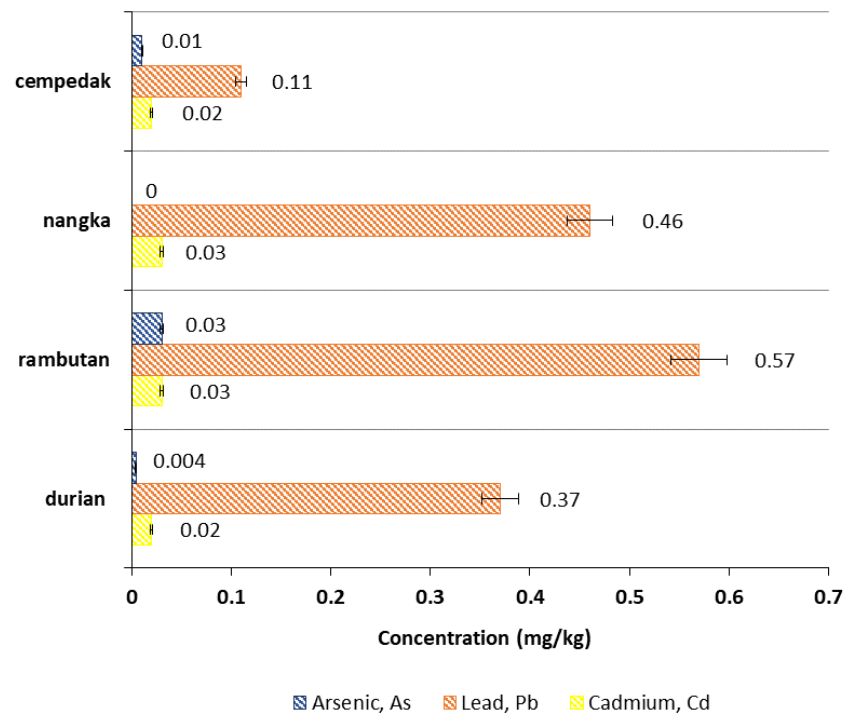

Figure 1. Heavy metal analytes detected in composite flours $(\mathrm{n}=3)$

\section{Conclusion}

Each composite flours has extinguished characteristic that enables the incorporation of the composite flours into new food product formulation. Protein gelation is vital in the preparation and acceptability of many foods, including vegetables and other products while foaming stability is useful in the food system such as confectionery products. Other properties such as WAC, OAC, $\mathrm{pH}$ and bulk density investigated in this study showed promising data and proposed that the composite flour from local are an ideal raw material to be utilized as semi and/or intermediate finish products in various food products and beverages. In addition, mineral analytes determined in these composite flour will add value to the products. All results obtained confirmed that the composite flours are safe to consume.

\section{Conflict of interest}

The authors declare is no conflict of interest.

\section{Acknowledgements}

This research was financially supported by Food and Nutraceutical Unit, Institute of Bioproduct Development (IBD), Universiti Teknologi Malaysia (UTM), Skudai. The authors would like also to thank Puan Norasiah binti Sadek for assistance with the laboratory work and Puan Siti Alyani Mat for assistance with the format editing.

\section{References}

Adebowale, K.O., Olu-Owolabi, B.I., Olawumi, E.K. and Lawal, O.S. (2005). Functional properties of native, physically and chemically modified breadfruit (Artocarpus artilis) starch. Industrial Crops and Products, 21(3), 343-351. https:// doi.org/10.1016/j.indcrop.2004.05.002

Akanbi, T.O., Nazamid, S. and Adebowale, A.A. (2009). Functional and pasting properties of a tropical breadfruit (Artocarpus altilis) starch from Ile-Ife, Osun State, Nigeria. International Food Research Journal, 16, 151-157.

Akintayo, E.T., Oshadi, A.A. and Esuoso, K.O. (1999) Effect of $\mathrm{NaCl}$, ionic strength and $\mathrm{pH}$ on the foaming and gelation of pigeon pea (Cajanus cajan) protein concentrates. Food Chemistry, 66, 51-56. https:// doi.org/10.1016/S0308-8146(98)00155-1

Anon, A.H., Fagbohoun, J.B., Ekissi, E.S.G., Yapi, J.C. and Kouame, L.P. (2018). Chemical composition and nutritional value of composite wheat flours (Triticumaestivum) and two varieties of taro corms (Colocasiaeculenta) cultivar Foue and cultivar Yatan. IOSR Journal of Environmental Science, Toxicology and Food Technology, 12(8), 24-28.

AOAC. (1975). Official methods of Analysis, $18^{\text {th }}$ ed. Washington, DC: AOAC.

Appiah, F., Oduro, I. and Ellis, W.O. (2011). Proximate and mineral composition of Artocarpus altilis pulp flour as affected by fermentation. Pakistan Journal of Nutrition, 10(7), 653-657. https://doi.org/10.3923/ pjn.2011.653.657

Bier D.M., Jim, M., Alpers, D.H., Vorster, H.H.E. and Gibney, M.J. (2015). Nutrition for the Primary Care Provider. Basel, Switzerland: Karger Publishing. https://doi.org/10.1159/isbn.978-3-318-02667-2

Chandra, S. and Samsher. (2013). Assessment of functional properties of different flours. African Journal of Agricultural Research, 8, 4849-4852.

Chandra, S., Singh, S. and Kumari, D. (2015). Evaluation of functional properties of composite flours and sensorial attributes of composite flour biscuits. Journal of Food Science and Technology, 52(6), 3681-3688. https://doi.org/10.1007/s13197$014-1427-2$ 
Chareonthaikij, P., Uan-On, T. and Prinyawiwatkul, W. (2016). Effects of pineapple pomace fibre on physicochemical properties of composite flour and dough, and consumer acceptance of fibre-enriched wheat bread. International Journal of Food Science and Technology, 51(5), 1120-1129. https:// doi.org/10.1111/ijfs. 13072

Chen, A.H. (2016). Characterization of functional properties of breadfruit flour (Artocarpus Altilis). Manoa: University of Manoa, MSc. Thesis.

Damasceno, K.A., Goncalves, C.A.A., Pereira, G.D.S., Costa, L L., Campagnol, P.C.B., Almeida, P.L.D. and Arantes-Pereira, L. (2016). Development of cereal bars containing pineapple peel flour (Ananas comosus L.MERRIL). Journal of Food Quality, 39 (5), 417-424. https://doi.org/10.1111/jfq.12222

Feili, R., Wahidu, Z., Wan Abdulla, W.N. and Tajul, A.Y. (2014). Physical and sensory analysis of high fiber bread incorporated with jackfruit rind flour. Food Science and Technology, 1(2), 30-36

Fennama, R.O. (1996). Food Chemistry. $3^{\text {rd }}$ ed. Florida: Kirk L. Parkin CRC Press.

Jitngarmkusol, S., Hongsuwankul, J. and Tananuwong, K. (2008). Chemical composition, functional properties and microstructure of defatted macadamia flours. Food Chemistry, 110(1), 23-30. https:// doi.org/10.1016/j.foodchem.2008.01.050

Kaushal, P., Kumar, V. and Sharma, H.K. (2012). Comparative study of physicochemical, functional, anti-nutritional and pasting properties of taro (Colocasia esculenta), rice (Oryza sativa), Pegion pea (Cajanus cajan) flour and their blends. LWTFood Science and Technology, 48(1), 59-68. https:// doi.org/10.1016/j.lwt.2012.02.028

Lebwohl, B., Sanders, D.S. and Green, P.H.R. (2017). Coeliac disease. The Lancet, 391(10115), 70-81. https://doi.org/10.1016/S0140-6736(17)31796-8

Makri, E., Popalamprou, E. and Doxastakis, G., (2005). Study of functional properties of seed storage proteins from indigenous European Legume crops (Lupin pea, broad bean) in admixture with polysaccharides. Food Hydrocolloids, 19(3), 583594. https://doi.org/10.1016/j.foodhyd.2004.10.028

Malaysian Food Regulation. (1985). Malaysian Law on Food and Drugs. Kuala Lumpur: Malaysian Law Publishers.

Menon, L., Majumdar, S.D. and Ravi, U. (2014). Mango (Mangifera indica L.) kernel flour as a potential ingredient in development of composite flour bread. Indian Journal of Natural Products and Resources, 5 (1), 75-82.

Moore, M.M., Heinbockel, M., Dockery, P., Ulmer H.M. and Arendt, E.K. (2006). Network formation in gluten-free bread with application of transglutaminase. Cereal Chemistry, 83(1), 28-36. https://doi.org/10.1094/CC-83-0028

Nurul Izzah, A., Aminah, A., Md Pauzi, A., Lee, Y.H., Wan Rozita, W.M. and Siti Fatimah, D. (2012). Patterns of fruits and vegetable consumption among adults of different ethnics in Selangor, Malaysia. International Food Research Journal, 19(3), 10951107.

Oladele, A.K. and Aina, J.O. (2007). Chemical composition and functional properties of flour produced from two varieties of tigernut (Cyperus esculentus). African Journal of Biotechnology, 6, 2473-2476. https://doi.org/10.5897/AJB2007.0002391

Oulai, S.F., Kouassi-Koffi, J.D., Gonnety, J.T., Faulet, B.M., Dje, M.K. and Kouame, L.P. (2014). Treatments effects on functional properties of breadfruits (Artocarpus altilis) pulp flour harvested in Cote d'Ivoire. International Journal of Recent Biotechnology, 2(4), 1-12.

Papa Spada, F, da Silva, P.P.M., Mandro, G.F., Margiotta, G.B., Spoto, M.H.F. and CanniattiBrazaca, S.G. (2018). Physicochemical characteristics and high sensory acceptability in cappuccinos made with jackfruit seeds replacing cocoa powder. PLoS ONE, 13(8), 1-12. https:// doi.org/10.1371/journal.pone.0197654

Rohman, A.D. (2017). Physico-chemical properties and biological activities of Rambutan (Nephelium lappaceum L.) Fruit. Research Journal of Phytochemistry, 11(2), 66-73. https:// doi.org/10.3923/rjphyto.2017.66.73

Tortoe, C., Johnson, P.-N.T., Slaghek, T., OduroYeboah, C., Addo, P., Nyarko, A. and Tamakloe, I. (2014). Physicochemical, proximate and sensory properties of organic side-stream pineapple (Ananas sp.), Flour. International Journal of Food Science and Nutrition Engineering, 4(1), 1-8.

Wani, A.A., Singh, P.O., Shah, M.A., SchweiggertWeisz, U., Gul, K. and Wani, I.A. (2012). Rice starch diversity: Effects on structural, morphological, thermal, and physicochemical properties-A review. Comprehensive Reviews in Food Science and Food Safety, 11(5), 417-436. https://doi.org/10.1111/ j.1541-4337.2012.00193.x 